\title{
PROFILE OF PATIENTS WITH GASTROINTESTINAL STROMAL TUMORS (GIST)
}

Perfil de pacientes portadores de tumores estromais gastrointestinais (GIST)

Eduardo Marcucci PRACUCHO, Luiz Roberto LOPES, Renato Morato ZANATTO, Karla Thaisa TOMAL,

Celso Roberto PASSERI, Joel Roberto Sagioro MOLAN, Ari de Almeida PRADO

From the Hospital Amaral Carvalho (Amaral Carvalho Hospital), Jaú, SP, Brazil.

HEADINGS - Gastrointestinal stromal tumors. Survival rate. Risk factors. Surgery.
ABSTRACT - Background: There is an improvement on the GIST treatment in last decade due to biomolecular research and adjuvant therapy with tyrosine kinases inibitors. However, both modalities of treatment rarely are available in Brazilian public hospital. Aim: Evaluate GIST patients profile in public oncologic hospital. Methods: A retrospective study was made on patients with GIST diagnosed and treated between 2001 and 2013. Results: Sixty-nine patients were included, mean age 59 years with slight predominance in females (51\%). The main symptom was abdominal pain associated with incidental imaging finding. The occurrence of other associated neoplasm was in $28.8 \%$ of cases. The positivity of CD117 was $97.1 \%$. The most frequent location was the stomach in $55.1 \%$ of cases. The R0 resection was possible in $63.8 \%$ and the recurrence rate was $20.3 \%$, with liver and peritoneum the main affected sites. Overall survival in the whole sample was $71 \%$. Free survival rate of disease was $64 \%$. The use of imatinib was limited to patients with residual disease (unresectable disease, R2 and R1 resection), metastatic disease or recurrence. Conclusion: In order to improve GIST treatment is necessary to add the biomolecular analysis to risk stratification. However, for this to occur, incentive in biomolecular research is required, to increase the possibility of patient survival.

\section{Correspondence:}

Eduardo Marcucci Pracucho,

email:epracucho@yahoo.com.br

Financial source: none

Conflicts of interest: none

Received for publication: 09/01/2015 Accepted for publication: 10/03/2015

DESCRITORES - Tumores do estroma gastrointestinal. Taxa de sobrevida. Fatores de risco. Cirurgia.
RESUMO - Racional: O tratamento do GIST tem se aprimorado muito na última década através das pesquisas biomoleculares e o uso adjuvante dos inibidores das tirosinas quinases. Entretanto, nos hospitais públicos brasileiros nem sempre são disponíveis tais ferramentas. Objetivo: Avaliar o perfil dos pacientes portadores de GIST em hospital público oncológico. Métodos: Análise retrospectiva de todos os casos de GIST tratados no período de 2001 a 2013. Resultados: Analisaram-se 69 pacientes, com média de idade de 59 anos e com discreto predomínio no sexo feminino (51\%). A principal forma de apresentação clínica foi dor abdominal associada com achado de exame de imagem. A ocorrência de outra neoplasia associada foi de $28,8 \%$. A positividade do CD117 foi de $97,1 \%$. A localização mais frequente foi o estômago em $55,1 \%$. A ressecção R0 foi possível em $63,8 \%$ dos casos e a taxa de recidiva foi de $20,3 \%$, sendo fígado e peritôneo os sítios principais acometidos. A sobrevida global na amostra toda foi de $71 \%$. A taxa de sobrevida livre de doença foi de $64 \%$. A utilização do imatinibe ficou restrita aos pacientes com doença residual (ressecção R2, R1 ou metastáticos), irressecáveis ou com recidiva. Conclusão: Afim de aprimorar o tratamento do GIST é necessário acrescentar a análise biomolecular à estratificação de risco. Porém, para que isto ocorra, políticas de incentivo e fomento na pesquisa biomolecular são necessárias, ampliando a possibilidade de sobrevida dos pacientes.

\section{INTRODUCTION}

A mong the cancers of the digestive tract, the stromal gastrointestinal tumors (connective tissue) have gained prominence within the clinical research. The precursor cells from these tumors are interstitial cells of Cajal, located in the wall of the gastrointestinal tract and make the connection with the smooth muscle to autonomic nerve plexus. Are pluripotent cells with neuronal characteristics such as smooth muscle cells being called "pacemaker" of peristalsis ${ }^{15}$.

Historically, these tumors were studied since 1940 and for a long time were confused as sarcomas of smooth muscles ${ }^{2}$. The use of electron microscopy and the advent of immunohistochemical, the gastrointestinal stromal tumor was named GIST in 1983 by Mazur and Clark ${ }^{17}$ and was ratified in 1998 with Kindblon ${ }^{15}$ and Hirota ${ }^{10}$ through the demonstration of the CD34 antigen (mesenchymal cell marker hematopoietic precursor) and CD117 (C-kit protein). 
In the begining, the positivity for CD34 gave the title "GIST" myogenic and other neuronal tumors ${ }^{21}$, while after the use of CD117, these tumors were removed from GIST diagnosis due to its negative CD117 .

The CD117 cell surface antigen is the extracellular portion of transmembrane protein tyrosine kinase which is the product of the KIT proto-oncogene. Thus, approximately $80 \%$ of GISTs, the mutation in this gene leads to activation of protein and triggers hyperplasia cellular process ${ }^{28}$

In 2001, the ACH started the immunohistochemical analysis for the detection of CD117 (C-kit) in order to diagnose cases of GIST and, so, include them in treatment protocols as disease staging. Thus, Amaral Carvalho Hospital has become a reference center for the treatment of this rare type of tumor.

Therefore, the objective of this study was to analyze the profile of patients treated and to identify possible gaps in treatment that can be improved.

\section{METHODS}

This research was approved by the Research Ethics Committee of the Institution ( SISNEP/CONEP) under number 138/11.

A retrospective study of all cases of GIST diagnosed from 2001 to 2013 was done. After the survey, the medical records were analyzed and demographics, medical history, location and tumor size, immunohistochemical profile, mitosis number by 50 fields, associated malignancies and disease-free interval and overall survival. The risk stratification group guidelines followed were: NIH ( National Institute of Health ) modified by Joenssu ${ }^{14}$, AFIP (Armed Forces Institute of Pathology) 2006, MSKCC Nomogram (Memorial Sloan Kettering Cancer Center) and TNM classification 2010 (UIJCC).

Data were computerized in the program SPSS19. Survival analysis and cumulative incidence were obtained by the Kaplan- Meier method. Statistical analysis of significance was performed by Long rank. The significance level was 5 $\%$ probability $(p=0.05)$. Other results were distributed in graphics and tables with averages, medians and minimum and maximum values

RESULTS

After analysis of 77 charts with histological diagnosis of spindle cell neoplasm, were eliminated eight cases due to loss of follow-up. Thus, 69 cases were included with confirmed diagnosis of GIST, either by immunohistochemical or by phenotypic profile of the analyzed blade. Among the cases $97.1 \%$ were positive for CD117 and 87\% for CD 34 . The two cases C-kit negative, GIST was considered by the pathologist due to its expression (Table 1 ).

TABLE 1 - Immunohistochemical profile

\begin{tabular}{|c|c|}
\hline Immunohistochemical & $\mathbf{n}(\%)$ \\
\hline CD117 & $67(97,1)$ \\
\hline CD34 & $60(87)$ \\
\hline Vimentin & $24(34,8)$ \\
\hline Smooth muscle actin & $25(36,2)$ \\
\hline Desmin & $11(15,9)$ \\
\hline S-100 & $11(15,9)$ \\
\hline H-Caldesmon & $25(36,2)$ \\
\hline Specific muscle actin (HHF-35) & $17(24,6)$ \\
\hline CD68 & $1(1,4)$ \\
\hline CD10 & $1(1,4)$ \\
\hline
\end{tabular}

The age ranged from 15 to 88 years, mean 59 . About $75 \%$ of cases were over 50 years, $22 \%$ between 20 and 50 years and only $3 \%$ below 20 years, with slight predominance of females $(51 \%)$. The white race was the most prevalent with $97 \%$ of cases. Most patients (64\%) were from other geographic region in relation to the hospital site.

The abdominal pain associated with tumor findings in imaging (ultrasound or abdomen CT) were the most frequent (31.9\%). Only 10 patients (14.5\%) presented with upper gastrointestinal bleeding. Sixteen cases (23.2\%) were an intra-operative incidental finding.

The preferred location was the stomach $(n=39,55.1 \%)$, followed by the small intestine $(n=18,26.1 \%)$, retroperitoneum $(n=8,11.6 \%)$ and rectum $(n=2)$, duodenum $(n=1)$, esophagus $(n=1)$ and colon $(n=1)$, totaling approximately $7 \%$. The presence of malignancy associated was in $28.8 \%$ of cases. The three most frequent tumors were adenocarcinoma of stomach $(n=8)$, prostate $(n=4)$ and colon $(n=4)$.

The gold standard treatment whenever possible was surgery with complete resection (Ro resection). However, it was not possible in approximately $1 / 3$ the cases.

In two cases of stomach involvement were identified positive lymph node. These patients received adjuvant imatinib for being considered with residual disease. One patient with primary site in stomach received neoadjuvant treatment with imatinib scheme to be considered initially unresectable and, after 10 months, underwent $\mathrm{R} 0$ resection.

Most were $>10 \mathrm{~cm}(34.8 \%)$ with an average size of 8 $\mathrm{cm}$ ranging from 0.6 to $28 \mathrm{~cm}$. Regarding the mitotic index, $76.8 \%$ had $<5 / 50$ fields, $18.8 \%>5 / 50$ fields of which three cases were not evaluated. Histological type mostly found was spindle cell (91.3\%) followed by mixed in $5.8 \%$ and $2.9 \%$ epithelioid.

Among 57 R0 resection $18.5 \%(n=13)$ developed recurrence, and the liver was the most affected organ (85.7\%). Underwent salvage surgery four cases: one enucleation of liver metastasis, one left hepatectomy, one nodule resection of the abdominal wall and one partial colectomy with hysterectomy.

Twenty nine patients were submitted to imatinib, 13 cases of recurrence, six of unresectable lesions, seven of $\mathrm{R} 2$ resection, two of node-positive and one case was treated with adjuvant imatinib due to high risk of recurrence (this patient had private health insurance). The response rate to imatinib showed $69 \%$ partial response and $31 \%$ with complete response ${ }^{8}$. The overall 5 -year survival of patients receiving imatinib was $43 \%$. Patients considered unresectable had exclusively imatinib therapy presenting global survive in $50 \%$.

The adverse effects of imatinib were identified in nine cases, mostly with nephrotoxicity (17.2\%). Among other adversities, two had cardiotoxicity, one leucopenia and one dyspeptic syndrome.

Overall survival in five years was $74 \%$ and the patients submitted to imatinib had a worse survival, 57\%. However, among this group are patients with metastases at the moment of admission, irressecable patients, residual disease and tumor recurrence (13/29 it means $44.8 \%)$ justifying the group to have with worse prognosis.

\section{DISCUSSION}

GISTs are rare tumors, represent $1-3 \%$ of tumors of the gastrointestinal tract and $80 \%$ of gastrointestinal mesenchymal tumors. It mainly affects patients with a mean age of 60 years ${ }^{20}$. The occurrence under 40's is rare ranging from $5-20 \%$. When present under 18 , GIST is classified as pediatric, or also called GIST SDH deficient, representing less than $1 \%$ of the cases ${ }^{24}$. The average age in this series 
was 59 years with two cases (2\%) less than 20 years.

The preferred location of GIST is the stomach, followed by the small intestine, colon, rectum and esophagus ${ }^{18}$. They are also called e-GIST (extra-gastrointestinal stromal tumor) when located outside the gastrointestinal tract ${ }^{9}$. Among the e-GIST were identified eight (11.6\%) all in retroperitoneum.

The clinical presentation is variable and can be diagnosed as palpable abdominal mass associated with imaging or endoscopic finding, or during the investigation of a digestive hemorrhage. There are other symptoms such as anorexia, weight loss, nausea, dysphagia or intestinal obstruction ${ }^{6}$. In this series the symptom of abdominal pain accompanied by the imaging finding was the most common clinical presentation, followed by palpable mass.

The literature shows positivity for CD117 around 95$98 \%{ }^{25}$. Other markers such as CD34, SMA, S -100 protein and Desmin respectively range from $60-70 \%, 30-40 \%, 5 \%$ and $<1 \%$. This sample showed $97,1 \%$ positives for CD117 and $87 \%$ for CD34.

Surgery with $\mathrm{RO}$ resection is the gold standard treatment for these tumors in $70 \%$ of cases of non metastatic disease ${ }^{8}$. Among 69 cases, 56 (81.2\%) underwent R0 resection (17.4\% requiring multiple resection due to adjacent organ invasion).

The literature recurrence rate in five years ranges from $10-40 \%$ in resectable patients ${ }^{19}$. The sample recurrence was $19,7 \%$, whereas when patients stratified as NIH 2008 high risk group was 30,4\%, AFIP2006 high risk was 38\%, MSKCC Nomogram (considering $>50 \%$ as high risk) was $41 \%$ and TNM 2010 (considering IIIA and IIIB as high risk) was 36\%.

The preferred site of recurrence is the liver followed by peritoneum ${ }^{6}$. This study found the same sites, with the liver responsible for $85.7 \%$ and the peritoneum by $42.8 \%$ of the recurrent cases.

The association with other cancers is previously known in the literature ${ }^{1}$. By definition all GIST are malign neoplasm ${ }^{25}$. The main factors that affect the prognosis is the size and the number of mitoses per microscope field identified by NIH criteria - also called Fletcher ${ }^{8}$ criteria -, the primary location site according to AFIP (Armed Forces Institute of Pathology) created in 2006 by Miettinen ${ }^{19}$ and finally if there is rupture or not, analyzed by Joensuu in $2008^{14}$. In 2009, in order to creating a tool that would facilitate risk stratification the Memorial Sloan-Dettering Cancer Center has created a nomogram that automatically calculate tumor size, the number of mitoses in 50 fields of microscopy and the primary site, resulting the risk of recurrence at five years after surgery with complete lesion resection ${ }^{3}$. In 2010 the American Joint Committee on Cancer together with other organizations defined a TNM staging for GIST posted on its $7^{\text {th }}$ edition manual ${ }^{7}$. Thus, it can be used different classifications for stratified the risk of recurrence. This sample was analyzed according to AFIP 2006 modified, NIH 2008, TNM and the nomogram criteria.

Imatinib is allowed in Brasilian National Health System in restricted cases mainly in unresectable cases and metastatic or residual disease after resection. Among 69 patients only one received adjuvant treatment (this patient had private health insurance). Thus, after resection and implementation of risk stratification it was rated high risk, therefore received adjuvant imatinib for three years as established in the literature ${ }^{13}$.

Overall survival in five years was $74 \%$, with 18 deaths in 12 years of follow-up; however, includes patients treated with imatinib. Patients treated with surgery alone were 40 with global survive of $86 \%$ in five years, and six deaths in this group, three were for general causes (myocardial infarction and stroke) and three by other cancers (stomach and lung). Overall survival in literature ranges $28-84 \%$ in five years ${ }^{12,22}$. This disparity occurred because survival is not assessed separately as the risk stratification of each patient groups. The high risk group survival was $65 \%$ for NIH2008, 71\% for AFIP2006 and for MSKCC Nomogram, and $81 \%$ for TNM2010. Whereas the overall survival of patients that did not receive imatinib $(n=40)$ was $86 \%$ versus $43 \%(n=29)$ for patients that received imatinib therapy (in this group, 13 were recurrence cases).

The mean survival of unresectable or $\mathrm{R} 2$ resection in literature ${ }^{3}$ ranges from 18 (pre-imatinib era) to 60 months. The overall survival of unresectable patients and $R 2$ resected was 33.6 months and 36 months respectively. Both received imatinib. The use of imatinib revolutionized the treatment of GIST and is the gold standard treatment according to the risk stratification ${ }^{26}$.

However, there are few cases (around 10\%) in which KIT expression does not occur. A portion of these cases (less than $4 \%)^{11,18}$ mutation occurs in other tyrosine kinase receptor, the receptor-alpha gene derived growth factor platelet (PDGFRA). Not least, there is a small class of GIST negative KIT and PDGFRA negative, known as "wild" type. This class seems to have mutations related to four genes involved in the production of succinate dehydrogenase $(\mathrm{SDH})^{23}$ and in a gene called BRAF, frequent in patients with melanoma. This group is associated with more sporadic GIST present in syndromes such as Carney-Stratakis and are more resistant to imatinib ${ }^{5}$.

Such biomolecular aspects are important, because as the mutations present in those components, information about the resistance to imatinib can be obtained (Table 2).

\section{TABLE 2 - Molecular GIST classification}

\begin{tabular}{l|l}
$\begin{array}{l}\text { KIT } \\
\text { Exon } 11\end{array}$ & first site common mutation $(66,9 \%)$ \\
$\begin{array}{l}\text { Exon } 9 \\
\text { Exon } 13 \& 17\end{array}$ & second site common mutation $(9,8 \%)$ \\
\hline $\begin{array}{l}\text { PDGFR } \alpha \\
\text { Exon } 12 \& 14 \\
\text { Exon } 18\end{array}$ & rare site mutation $(2 \%)$ \\
\hline $\begin{array}{l}\text { wild type (KIT negative e } \\
\text { PDGFR } \text { negative) }\end{array}$ & uncertain molecular etiology \\
\hline $\begin{array}{l}\text { GIST family } \\
\text { Pediatric }\end{array}$ & gernimative line mutation ok KIT and PDGFR $\alpha$ \\
\hline $\begin{array}{l}\text { Carney's Triad } \\
\text { Neurofibromatosis type1 } 1\end{array}$ & absent mutation in KIT and PDGFR $\alpha$ \\
\hline
\end{tabular}

Thus, mutations in exon 9,11,13 and 17 of KIT and 12 and 14 of PDGFR indicate sensitivity to imatinib. In contrast, mutations in exon 18 (D842V) of PDGFR suggest low response to imatinib.

In 2004, was discovered another protein that helps immunohistochemical assessment of diagnosis process of GIST with KIT negative and negative PDGFR: DOG1 (Discovered on Gist-1) also known as anoctamin1 through the expression of the FLJ10261 gene, present in $98 \%$ of GISTs ${ }^{16,27}$ and in a minority of other sarcomas.

\section{CONCLUSION}

In order to improve GIST treatment is necessary to add the biomolecular analysis to risk stratification. However, for this to occur, incentive in biomolecular research is required, to increase the possibility of patient survival. 
REFERENCES

1. Agaimy $A$, Wünsch $P H$, Sobin LH, Lasota J, Miettinen M. Occurrence of other malignancies in patients with gastrointestinal stromal tumors. Semin Diagn Pathol. 2006 May;23(2):120-9.

2. Appelman HD:Mesenchymaltumors of the gut:Historical perspectives, new approaches, new results and does it make any difference? Monogr Pathol 31:220-246, 1990.

3. Blanke CD, Demetri GD, von Mehren $M$, Heinrich $M C$, Eisenberg B, Fletcher JA, Corless CL, Fletcher CD, Roberts PJ, Heinz D, Wehre $E$, Nikolova $Z$, Joensuu $H$. Long-term results from a randomized phase II trial of standard- versus higher-dose imatinib mesylate for patients with unresectable or metastatic gastrointestinal stromal tumors expressing KIT, J Clin Oncol 26 (2008), pp. 620-625.

4. Choi H, Charnsangavej C, Faria SC, Macapinlac HA, Burgess MA, Patel SR, Chen LL, Podoloff DA, Benjamin RS. Correlation of Computed Tomography and Positron. Emission Tomography in Patients With Metastatic. Gastrointestinal Stromal Tumor Treated at a Single Institution With Imatinib Mesylate: Proposal of New. Computed Tomography Response Criteria. J Clin Oncol 25:1753-1759.2007.

5. Corless CL, Fletcher JA, Heinrich MC. Biology of gastrointestinal stromal tumors. J Clin Oncol. 2004;22:3813-3825.

6. DeMatteo RP, Lewis JJ, Leung D, Mudan SS, Woodruff JM, Brennan MF. Two hundred gastrointestinal stromal tumors: recurrence patterns and prognostic factors for survival. Ann surg 2000; 231-51.

7. Edge SE, DR Byrd, MA Carducci, CC Compton, eds. AJCC Cancer Staging Manual. $7^{\text {a }}$ ed . New York, NY: Springer, 2010.

8. Fletcher CD, Berman JJ, Corless C, Gorstein F, Lasota J, Longley BJ Miettinen M, O'Leary TJ, Remotti H, Rubin BP, Shmookler B, Sobin LH, Weiss SW. Diagnosis of gastrointestinal stromal tumors: A consensus approach. Hum Pathol 2002; 33:459-465.

9. Gastrointestinal stromal tumours: a regular origin in the muscularis propria, but an extremely diverse gross presentation. A review of 200 cases to critically re-evaluate the concept of so-called extragastrointestinal stromal tumours.

10. Hirota S, Isozaki K, Moriyama Y, Hashimoto K, Nishida T, Ishiguro S Kawano K, Hanada M, Kurata A, Takeda M, Tunio GM, Matsuzawa Y, Kanakura H, Shinomura Y and Kiramura Y (1998) Gain-of-function of c-Kit in human gastrointestinal stromal tumors. Science 279 : 577-580.

11. Hirota s, Isozaki K. Pathology of gastrointestinal stromal tumors. Pathol int. 2006 Jan;56(1):1-9.

12. Hsu KH, Yang TM, Shan YS, Lin PW. Tumor size is a major determinant of recurrence in patients with resectable gastrointestinal stromal tumors. Am J Surg 2007;194(2):148-52.

13. Joensuu H, Eriksson M, Sundby Hall K, Hartmann JT, Pink D, Schütte J, Ramadori G, Hohenberger P, Duyster J, Al-Batran SE, Schlemmer M, Bauer S, Wardelmann E, Sarlomo-Rikala M, Nilsson B, Sihto $H_{\text {, }}$ Monge $\mathrm{OR}$, Bono $\mathrm{P}$, Kallio $\mathrm{R}$, Vehtari $\mathrm{A}$, Leinonen $\mathrm{M}$, Alvegård $\mathrm{T}$, Reichardt P.. One vs three years of adjuvant imatinib for operable gastrointestinal stromal tumor:a randomized trial. JAMA 2012; 307: 1265-72.
14. Joensuu H. Riskstratification of patients diagnosed with gastrointestinal stromal tumor. Hum Pathol 2008;39:1411-9.

15. Kindblom LG, Remotti HE, Aldenborg Fand Meis-Kindblom JM (1998) Gastrointestinal pacemaker cell tumor (GIPACT). Gastrointestinal strom tumors show phenotypic characteristics of the interstitial cells of Cajal. Am J Pathol 152: 1259-1269.

16. Liegl B, Hornick JL, Corless CL, Fletcher CD.. Monoclonal antibody DOG1.1 shows higher sensitivity than KIT in the diagnosis of gastrointestinal stromal tumors, including unusual subtypes. Am J Surg Pathol 2009;33(3):437-46.

17. MazurMT, ClarkHB. Gastric stromal tumor. Reappraisal of histogenesis. Am J Surg Pathol 1983;7:507-519.

18. Miettinen M, Lasota J. Gastrointestinal stromal tumors: review on morphology, molecular pathology, prognosis, and differential diagnosis. Arch Pathol Lab Med. 2006 oct;130(10):1466-78.

19. Miettinen M, Sobin LH, Lasota J. Gastrointestinal stromal tumors of the stomach: a clinicopathologic, immunohisto- chemical, and molecular genetic study of 1765 cases with long-term follow-up. Am J Surg Pathol 2005;29:52-68.

20. Miettinen M. Lasota J.Gastrointestinal Stromal Turmors. Gastroenterol Clin N Am 42 (2013) 399-415.

21. Newman PL, Wadden C, FletcherCD. Gastrointestinal stromal tumours: correlation of immunophenotype with clinicopathological features. J Pathol 1991; 164:107

22. NgEH, PollockRE, Munsell MF, AtkinsonEN, Romsdahl MM. Prognostic factors influencing survival in gastrointestinal leiomyosarcomas. Implications for surgical management and staging. Ann Surg 1992;215(1):68-77.

23. Pantaleo MA, Astolfi A, Indio $V$, Moore $R$, Thiessen $N$, Heinrich $M C$ Gnocchi C, Santini D, Catena F, Formica S, Martelli PL, Casadio R, Pession A, Biasco G. SDHA loss-of-function mutations in KIT-PDGFRA wild-type gastrointestinal stromal tumors identified by massively parallel sequencing. J Natl Cancer Inst 2011; 103:983.

24. Prakash S, Sarran L, Socci N, DeMatteo RP, Eisenstat J, Greco AM, Maki RG, Wexler LH, LaQuaglia MP, Besmer P, Antonescu CR. Gastrointestinal Stromal Tumors in Children and Young Adults. A Clinicopathologic, Molecular, and Genomic Study of 15 Cases and Review of the Literature. J Pediatr Hematol Oncol Volume 27, Number 4, April 2005.

25. Raul CP, Morgan JA, Ashley SW. Current issues in gastrointestinal stromal tumors: incidence, molecular biology, and contemporary treatment of localized and advanced disease. Current Opinion Gastroenterology. 2007;23:149-58.

26. Reichardt P, Blay JY, Mehren M. Towards global consensus in the treatment of gastrointestinal stromal tumor. Expert Rev. Anticancer Ther. 10(2), 221-232 (2010)

27. West RB, Corless CL, Chen X, Rubin BP, Subramanian S, Montgomery K, Zhu S, Ball CA, Nielsen TO, Patel R, Goldblum JR, Brown PO, Heinrich MC, van de Rijn M. The novel marker, DOG1, is expressed ubiquitously in gastrointestinal stromal tumors irrespective of KIT or PDGFRA mutation status. Am J Pathol 2004;165(1):107-13.

28. Williams DE, Eisenman J, Baird A, Rauch C, Van Ness K, March CJ, Park LS, Martin U, Mochizuki DY, Boswell HS, Burgess GS, Cosman $\mathrm{D}$, Lyman SD. Identification of a ligand for the c-kit proto-oncogene. Cell. 1990:63:167-174. 